CURRENT RESEARCH JOURNAL OF PHILOLOGICAL SCIENCES 2(10): 54-

58, October 2021

DOI: https://doi.org/10.37547/philological-crjps-02-10-11

ISSN 2767-3758

(C)2021 Master Journals

4. Crossref dol 8 Google

Accepted $26^{\text {th }}$ October, 2021 \& Published $31^{\text {th }}$ October, 2021

\title{
COMMUNICATIVE COMPETENCE AS A PROBLEM OF MODERN LINGUODIDACTICS
}

\author{
Guljakhon Shavkatjon Kizi Kholdorova
}

Master's Student, Specialty Of Russian Language And Literature, Kokand State Pedagogical Institute Named After Mukimi ,Uzbekistan

\section{ABSTRACT}

The article examines the current task of education - the formation of students' communicative competence, which is the main approach of linguodidactics, as well as its role in the effective coordination of professional activities of students of higher education. Communicative competence is a supra-professional competence that determines the ability of an individual to solve a certain range of tasks. Due attention is paid to the disclosure of the content of the basic concepts of "competence" and "adequacy", and generalized characteristics of grammatical, sociolinguistic, discursive and strategic competencies are given. The importance of applying competence-based and integrative approaches to learning is noted, the role of humanization and humanization of higher education is emphasized. The main objectives of the course "Pedagogy and Psychology" are outlined, aimed at the formation of general cultural, professional and general professional competencies of future specialists in higher education. The author focuses on the value of the competence-based approach in education, which consists in focusing on the personality of the student in all spheres and areas of activity. The communicative competence is considered by the author as the most important indicator of the teacher's professionalism. The decisive role in the effective formation of students' communicative competence is played by the conditions of communication, the educational environment created at the university.

KEYWORDS: - Communicative competence, linguodidactics, methodology, competence, competence-based approach, communication process, speech behavior, components of communicative competence, linguistics, psycholinguistics, level of communicative sufficiency, social situation, hierarchical learning system, grammatical competence, sociolinguistic competence.

\section{INTRODUCTION}

At the present stage of development in the method of teaching a language, there are three directions: linguodidactics, methodology and technology.

"Linguodidactics is a theory of language teaching, the integration of linguistics and didactics" [1, p. 23].

"The term "linguodidactics" is currently used to denote a discipline that studies the content, means and methods of teaching a native / nonnative language" [4, p. 6]. This term was introduced by the Soviet linguist Nikolai Maksimovich Shansky in 1969. It was recognized as international in 1975. Linguodidactics is currently considered as one of the levels (along with methodology and technology) of language teaching methodology. It is a theoretical language teaching discipline that arose at the intersection of linguistics and didactics.

THE MAIN FINDINGS AND RESULTS 
CURRENT RESEARCH JOURNAL OF PHILOLOGICAL SCIENCES 2(10): 54-

58, October 2021

DOI: https://doi.org/10.37547/philological-crjps-02-10-11

ISSN 2767-3758

(C)2021 Master Journals

Crossref do

8 Google

Accepted26 ${ }^{\text {th }}$ October, 2021 \& Published $31^{\text {th }}$ October, 2021

Under the influence of linguistic pragmatics, the communicative approach has been dominating in foreign language didactics for many years. In pedagogy, the definition of "competence" is an integrated result of mastering the content of the educational process, expressed in the readiness of students to apply knowledge, skills and abilities. Also the ability to apply methods of activity in different life situations in order to solve theoretical and practical problems. Competence - this concept is applied to a person's knowledge of the corresponding competence. If competence in pedagogy is a given norm of educational training, then competence is a personality quality that is necessary for high-quality, effective work in a certain area.

The term "communicative competence" in domestic science was first used by M.N. Vyatyutnev to denote a person's ability to communicate in work or study, satisfying his intellectual needs. Initially, this term was used in the methodology of teaching foreign languages, and then it was borrowed by representatives of other branches of science.

I.N. Zotova describes communicative competence as a system of psychological knowledge about oneself and others, skills, communication skills, strategies of behavior in social situations, allowing to build effective communication in accordance with the goals and conditions of professional and interpersonal interaction [7, p.22 ].

E.E. Sysoeva examines the concept of communicative competence from the point of view of formation. She characterizes the student's communicative competence as a certain level of formation of personal and professional experience of interaction with others, which is required for an individual in order to function successfully in society within the framework of his abilities and social status [9, p. 7]. "Situationalness", "situational relevance", "cooperation" is used by many researchers to define the concept of communicative competence.

Communicative competence is knowledge of a language, aimed not only at mastering language competence, but also the ability to use one's knowledge and skills in various spheres of social life. In this regard, 4 components of communicative competence are usually declared: 1) grammatical competence, which includes phonetics, spelling, vocabulary and syntax; 2) sociolinguistic: the ability to express expressions in which the meaning corresponds to specific situations; 3 ) discursive competence: the ability to build holistic, logically connected statements in written and spoken language; 4) strategic competence: the ability to compensate for their lack of knowledge of the language, as well as speech communication skills.

In the dictionary of methodological terms, communicative competence is understood as "the ability to solve by means of a foreign language the problems of communication that are relevant for students and society from everyday life, educational, industrial and cultural life; the student's ability to use the facts of language and speech for the realization of the goals of communication" [2, p. 109]. The acquisition of communicative competence by an individual becomes the main goal of training.

Today, communicative competence is defined "as the choice and implementation of speech behavior programs, depending on a person's ability to navigate in a particular communication environment; the ability to classify situations depending on the topic, tasks, communicative attitudes that arise in students before the conversation, as well as during the conversation in the process of mutual adaptation" [3;p. 44], i.e. 
CURRENT RESEARCH JOURNAL OF PHILOLOGICAL SCIENCES 2(10): 54-

58, October 2021

DOI: https://doi.org/10.37547/philological-crjps-02-10-11

ISSN 2767-3758

(C)2021 Master Journals

Crossref do

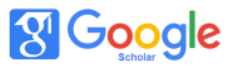

Accepted $26^{\text {th }}$ October, 2021 \& Published $31^{\text {th }}$ October, 2021

the ability to realize linguistic competence in various conditions of verbal communication, taking into account social norms and communicative expediency. The practical result of research in this area is reflected in the concepts of modern teaching, especially the Russian language. The main purpose of teaching a language is carried out through the formation of communicative competence. From a psychological point of view, communicative competence is, first of all, the individual ability of a person. This is the ability of a person to adequately organize the most diverse communication situations (by purpose, by role relationships, by form, by content, etc.) to organize his speech activity in its productive and receptive forms by linguistic means and methods corresponding to each specific situation.

A number of scholars identify four competencies in accordance with the main types of speech activity: competencies in speaking, reading, listening and writing. M.V. Vyatyutnev distinguishes two competences - production and perception, taking into account the process of generation and reception of speech [5, p. 79]. N. D. Galskova and N.I. Gez distinguishes the following components of communicative competence: 1) knowledge of the system of the target language and skills in operating linguistic means of communication; 2) formed on the basis of linguistic knowledge and language skills, the ability to understand and generate foreign language statements, combine them in the course of one act of communication in accordance with a specific communication situation, speech task and communicative intention; 3) knowledge of the socio-cultural specifics of the country of the target language, as well as skills and abilities that allow for verbal and non-verbal communication with native speakers of this language in accordance with the specifics and norms that regulate verbal interaction in the corresponding linguo-ethnocultural community [6, p. 100].

Teaching students the Russian language as a subject of study takes place in a hierarchical system of language teaching. In the hierarchical system of language functions, there are the main functions and their varieties - particular functions. The main functions of language are the mental function (that is, the function of formation, design and implementation of mental or, more broadly, mental activity and communicative (the function of communication) $[8$, p. 7]. Mastering a foreign language, communication in it is difficult precisely because it changes significantly the form of manifestation of thought processes, due to the originality of the language, social relations, categorical features, characteristics of the nomination.

As we noted, the main goal of teaching the Russian language is practical knowledge of it as a means of communication, cognition, thinking. E.P. Shubin clearly describes the parameters of the rational organization of the non-native language teaching system. In his opinion, one of the main characteristics of the training system should be a clearly defined communicative goal of training "the inclusion of the student in the exchange of information ... within the framework of a foreign language collective" or, in other words, "the creation of a psychophysiological communicator in the body of a trained psychophysiological communicator" [10, p.102]. In addition to the communicative goal, the scientist identifies a number of additional ones: educational impact, broadening the general educational horizons, improving thinking, etc.

The scientist also notes that "when determining the communicative goals of teaching languages, it is necessary to keep in mind the presence of two main levels of language proficiency - minimum and maximum" [10, p.106]. Or in other words: "the level of communicative sufficiency and the 
CURRENT RESEARCH JOURNAL OF PHILOLOGICAL SCIENCES 2(10): 54-

58, October 2021

DOI: https://doi.org/10.37547/philological-crjps-02-10-11

ISSN 2767-3758

(C)2021 Master Journals

Crossref do

8 Google

Accepted $26^{\text {th }}$ October, 2021 \& Published $31^{\text {th }}$ October, 2021

level of social sufficiency.

The maximum level - the level of social sufficiency "characterizes native speakers ... A foreigner who speaks the language to such an extent will be indistinguishable from native speakers at least in certain areas and types of communication. This means that the messages produced by it (oral or written) will not contain paralinguistic information that would "give out" the foreign origin of the transmitter, and the messages will be received correctly and at a rate corresponding to the norm of the given collective" [10, p. 102].

\section{Conclusion}

Thus, the communicative attitude, defining the content of the utterance, makes it necessary to isolate from the system of the language such linguistic means, the features of the functioning of which are most essential for the expression of this content. The modern methodology of teaching languages retains a service role for grammar, since mastering a language requires the acquisition of certain knowledge about the language. Learning tasks are to find the most radical ways of mastering grammatical actions that make up the automated components of speech activity, as well as ways of mastering the grammatical material with which these actions are performed. To do this, the teacher needs to identify the relationship between grammar (generalized, abstracted, systematized or processed linguistic material) and skills in various types of communicative activity, since the forms of language accompany thoughts already at the initial phase of its inception, forming together with it a single speech-thinking process. If training is carried out taking into account these relationships, then it will be effective.

\section{REFERENCES}

1. Ageeva A.V. (2015) Formation of students' communicative competence. New science: experience, traditions, innovations: International scientific periodical following the results of the International scientific and practical conference (October 24, 2015, Sterlitamak). / In 2 part, Part 1 Sterlitamak: RITS AMI. - p. 250.

2. Azimov, E.G. A new dictionary of methodological terms and concepts (theory and practice of teaching languages) E.G. Azimov, A.N. Shchukin. - M .: Publishing house IKAR. 20012. - p. 448.

3. Azimov, E.G. New dictionary of methodological terms and concepts (theory and practice of teaching languages). E. G. Azimov, A. N. Shchukin. - M .: Publishing house IKAR, 20012. - p. 448.

4. Vorozhtsova I.V. (2017) Basics of linguodidactics textbook for universities Izhevsk. - p. 360.

5. Vyatyutnev, M.N. Traditions and innovations in modern teaching methods of the Russian language. M.N. Vyatyutnev. Scientific traditions and new directions in teaching the Russian language and literature: Report. Delegation to the VI Congr. MAPRYAL. - M : Rus. yaz., 2010. - P.78-90.

6. Galskova, N.D., Gez, N.I. (2014) Theory of teaching foreign languages. Linguodidactics and methodology. N.D. Galskova. - Moscow. - p. 150.

7. Zotova I.N. (2016) Psychological and pedagogical support for the development of the communicative competence of students of a technical university: author. dis. Cand. psychol. Sciences: 19.00.07 /. - Stavropol. p. 22. 
CURRENT RESEARCH JOURNAL OF PHILOLOGICAL SCIENCES 2(10): 54-

58, October 2021

DOI: https://doi.org/10.37547/philological-crjps-02-10-11

ISSN 2767-3758

(C)2021 Master Journals

Crossref doi 81 Google

Accepted26 ${ }^{\text {th }}$ October, 2021 \& Published 31 ${ }^{\text {th }}$ October, 2021

8. Panfilov, V.Z. (2010) Philosophical problems of linguistics. Questions of linguistics. No. 3. - pp. 6-14.

9. Polat E. S. (2016) New pedagogical and information technologies in the education system. - Moscow: Academy. - pp. 272, 86.

10. Shubin E.P. (2011) Language communication and teaching foreign languages. E.P. Shubin. - Moscow. - p. 202. 